\title{
HISTORIA
}

\section{Josef Kolmaš}

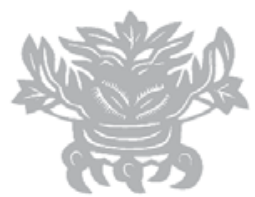

\section{AKOMODACJA \\ - POPRZEDNICZKA AGGIORNAMENTO? (Na przykładzie misji katolickich w Chinach w XVI-XVIII w.)'}

Kierowany troską, aby wewnętrzne i zewnętrzne życie kościoła rzymskokatolickiego uwolniło się od starych przesądów i barier oraz zostało ukierunkowane na zacieśnienie więzi z dobą współczesną, jej potrzebami i wyzwaniami, papież Jan XXIII (1958-1963) wypowiedział odważne hasło aggiornamento. W ostatecznym zamyśle miało to oznaczać całkowitą zmianę sposobu myślenia: odwrócenie się od dotychczasowej percepcji przeszłości i zmierzenie się z wyzwaniami współczesnego, odmienionego świata. W praktyce i doraźnie oznaczało to stopniowe przystosowywanie się do wymagań współczesnego życia we wszystkich jego głównych przejawach.

Nie wiemy, czy ojcowie drugiego soboru watykańskiego (1962-1965) zdawali sobie sprawę, że z czymś podobnym, choć oczywiście w zupełnie odmiennych historycznie i społecznie warunkach, kościół rzymskokatolicki zetknął się już w XVI-XVIII w. Wtedy to chrześcijaństwo, które dotąd utożsamiało się głównie ze śródziemnomorskim, a później europejskim kręgiem kulturowym, zaczęło w ślad za odkryciami geograficznymi poprzednich stuleci wychodzić poza ten obszar - do Afryki, Azji i Ameryki Południowej.

Jeśli ograniczymy swoje spojrzenie na dany temat wyłącznie do obszaru azjatyckiego, a w nim wyłącznie do jego najodleglejszej części - Chin, unaocznimy sobie wyraziście, na jakie problemy napotkało szerzenie chrześcijaństwa. W odkrytych przez Portugalczyków i Hiszpanów częściach świata, gdzie misjonarze chrześcijańscy mieli zazwyczaj do czynienia ze słabo zorganizowanymi wspól-

\footnotetext{
${ }^{1}$ Tekst pierwotnie opublikowany w „Universitní noviny” (pismo Uniwersytetu Masaryka i Fundacji Universitas Masarykiana), 30 listopada 1996, s. 28-33.
} 
Akomodacja - poprzedniczka aggiornamento?

notami szczepowymi i rodzimymi prymitywnymi religiami, chrześcijaństwu nie stawiano niemal żadnego oporu. Tak działo się głównie w Afryce oraz Ameryce Środkowej i Południowej (oczywiście także z tego powodu, że portugalscy i hiszpańscy zdobywcy potrafili w porę swoje kolonialne panowanie zabezpieczyć instytucjonalnie przy użyciu siły).

Inną sytuację i jakościowo inne problemy rodziło zetknięcie się zachodniego chrześcijaństwa ze starymi, skonsolidowanymi kulturami obszarów Wschodu - Indii, Chin i Japonii. Na terenach, gdzie tradycje kulturowe wyraźnie różniły się od europejskich, gdzie wytworzyły się odmienne systemy religijne (z reguły starsze od chrześcijaństwa) i panował całkowicie inny od europejskiego styl życia, szerzenie zachodniego chrześcijaństwa mogło spotkać się z nikłym zaledwie powodzeniem.

Bardziej dalekowzroczni szerzyciele chrześcijaństwa rychło uświadomili sobie, że propagowanie zachodniej wiary bez odpowiedniego przystosowania (akomodacji) do miejscowych warunków i tradycji, nie da pożądanego rezultatu. Oczywiście nie przypuszczali w swojej apostolskiej żarliwości, że głoszona przez nich $\mathrm{w}$ dobrej wierze akomodacja - czy to w wyniku rywalizacji działających w terenie zakonów i zgromadzeń misyjnych, czy to w wyniku niezrozumienia w kurii rzymskiej - zrodzi skomplikowany problem natury dogmatycznej, który w końcu dzieło misyjne pogrzebie, a przynajmniej sparaliżuje na długie stulecia.

Misjonarzem, który najbardziej zasłynął z ucieleśniania teorii i praktyki akomodacji w Indiach, był włoski jezuita Roberto de Nobili (1577-1656). Dla nadania większej skuteczności swojemu dziełu zaczął on wszechstronnie przystosowywać się do stylu życia i sposobu myślenia mieszkańców Indii: wiódł pełne wyrzeczeń życie hinduskiego pokutnika, przyswoił sobie święty język braminów - sanskryt, w swych kazaniach cytował święte hinduskie księgi, a Ewangelię Chrystusa wydawał jako jedną z uczonych ksiąg starohinduskich. W nauczaniu religii chrześcijańskiej dopuszczał, aby nawróceni zachowywali swoje hinduistyczne zwyczaje, jeśli tylko nie miały wyraźnie „pogańskiego” charakteru. Dla tak pojmowanej praktyki religijnej, zapoczątkowanej w południowych Indiach, przyjęto z czasem nazwę ,malabarskie rytuały” (od miejscowości, gdzie działał de Nobili). Stosowanie ich oznaczało drogę iście ciernistą, a w 1744 r. - w wyniku misjonarskiej zawiści i niezrozumienia ze strony papieża Benedykta XIV (1740-1758) - zakończyły swój byt przez ich ostateczne potępienie i zakaz szerzenia. Wielki hinduski myśliciel Mahatma Gandhi musiał jeszcze w XX w. dopominać się o chrześcijańską tolerancyjność, z wielką intuicją głoszoną i realizowaną przez Nobilego już przed czterema wiekami: „My w Indiach staliśmy się niewiarygodni, ponieważ nie jesteśmy zewnętrznie podobni do wyobrażeń kreowanych przez instytucje misyjne, które przyszły do nas z Zachodu. Nie mylcie tego, czego nauczał Jezus, z tym, co uchodzi za nowoczesną cywilizację! Pytam was, którzy jesteście Jego misjonarzami, czy przypadkiem nie zadajecie gwałtu ludziom, wśród których żyjecie? Zapewniam 
was, że nie jest waszym powołaniem wyrywanie ludzi Wschodu z ich korzeniami. Tolerujcie to, co jest w nich dobrego. Pozwólcie każdemu z nas żyć życiem własnym" (Über die Bergpredigt, [w:] M. Gandhi, Freiheit ohne Gewalt, Köln 1968).

Podobny los, jeśli nie jeszcze bardziej tragiczny, spotkał misje chrześcijańskie w Chinach. Trzeba jednak przyznać, jak już zaznaczyliśmy, że chrześcijaństwu szczególnie katolickiemu - nigdy w Chinach nie wiodło się, przeciwnie, obca wiara była nieraz przedmiotem ostrych ataków ze strony przedstawicieli oficjalnej ideologii państwowej, jaką był konfucjanizm. Nierzadkie były nawet przypadki, kiedy niepożądani głosiciele obcej religii musieli być wydalani z kraju.

Metodę akomodacji wprowadził do Chin założyciel tamtejszej misji jezuickiej, Włoch Matteo Ricci (1552-1610). Po czteroletnim doświadczeniu z praktyką malabarskich rytuałów w Indiach (1576-1582) przeniósł on swoją działalność do Chin, zrazu do Makau i Kantonu, a od roku 1601 do Pekinu, już na stałe. Tam, obok pracy misyjnej, poświęcił się głównie rozległej działalności naukowej w dziedzinie matematyki, mechaniki, chemii, medycyny, astronomii, geografii i kartografii. Większość prac z tych dziedzin opublikował po chińsku. Jego sposób przystosowania się do chińskiego środowiska, podobnie jak przystosowanie się jego przyjaciół i następców, polegał - oprócz czysto zewnętrznego naśladownictwa chińskiej mody w ubiorze, fryzurze itp. - na znakomitym opanowaniu języka chińskiego, przyswojeniu sobie znajomości historii narodu chińskiego, jego świeckich i duchowych tradycji itd., a także na nawiązaniu dialogu z miejscowymi uczonymi mandarynami. Już samo to było sposobem wyrażenia ustępstwa ze strony pojmowanego nadrzędnie chrześcijaństwa i uznania dla chińskiej wiedzy.

Tak światłemu narodowi z wielowiekową kulturą i tradycją religijną nie mógł Ricci przedstawiać nauki o istnieniu Boga, o chrześcijańskich prawdach i zasadach moralnych, jako czegoś zupełnie nowego, nieznanego Chińczykom. Przeciwnie, on sam i pozostali jezuiccy misjonarze, odmiennie niż inne zakony działające wówczas w Chinach, twierdzili, że naturalna stara chińska pobożność, wyobrażenia Chińczyków o Bogu itd., właśnie w chrześcijaństwie osiągają swoje wyżyny, a chrześcijańskie nauczanie, czy to objawione czy uświęcone tradycją, wiedzie do lepszego zrozumienia własnego dziedzictwa kulturowego. Wszelkie rodzime wartości chińskiej kultury miały być zachowane w przyjętym chrześcijaństwie. Wśród tych wartości miał oczywiście swoje miejsce zarówno kult przodków, jak i poszanowanie filozofa Konfucjusza, traktowane przez Ricciego jako pochodne narodowej tradycji. Chińscy cesarze zarówno z dynastii Ming (1368-1644), jak i następnej mandżurskiej dynastii Qing (1644-1912), pozytywnie oceniali taką postawę jezuitów, czego wyrazem były edykty tolerancyjne (np. z lat 1657 i 1692) oraz przyjazny stosunek do cudzoziemskiego nauczania i cudzoziemskich nauczycieli.

Spośród wszystkich sporów, jakie wywołało dotarcie katolicyzmu do Chin, swoją przewlekłością i subtelnością wyróżniał się spór o tzw. „chińskie rytuały” czy „obrzędy” (ritus, ewentualnie ceremoniae Sinenses), w którym swój udział mieli 
Akomodacja - poprzedniczka aggiornamento?

zarówno misjonarze działający w Chinach, jak i kuria rzymska. O co szło w tym sporze, jak przebiegał i jak się zakończył?

Już od niepamiętnych czasów cechował Chińczyków kult przodków i czczenie Konfucjusza. Nie chodziło przy tym o żadne buddyjskie czy taoistyczne praktyki, lecz o narodowy i ludowy zwyczaj oddawania czci zmarłym przodkom, a także o hołd, jaki składali chińscy literaci po zdanych egzaminach urzędniczych wielkiemu filozofowi chińskiej starożytności. Obie te powinności, polegające na oddawaniu pokłonu przed tabliczką z wypisanym na niej imieniem zmarłego, na paleniu kadzidła i zanoszeniu na groby symbolicznych potraw i pieniędzy (co do pewnego stopnia przypomina modlitwy za dusze zmarłych i czczenie świętych w kościele katolickim), spotykały się u wczesnych szerzycieli chrześcijaństwa z Riccim na czele z wielkoduszną tolerancją, a wśród nawróconych na chrześcijaństwo Chińczyków ze zrozumieniem. Ricci sądził, że zwyczaje te nie przetrwają wśród chińskich chrześcijan zbyt długo i automatycznie zanikną w miarę, jak ich wiara będzie się pogłębiać i umacniać (w przypadku kultu przodków nabierze on charakteru chrześcijańskich „zaduszek”).

Sprzeciw wobec tych ,pogańskich” praktyk i pobłażliwego do nich stosunku jezuitów zgłosili najpierw miejscowi misjonarze franciszkanie, do których później przyłączyli się inni. Oni to właśnie, jednoznacznie upatrując w kulcie przodków zabobonu, a w oddawaniu czci Konfucjuszowi - modlitwy, domagali się stanowczo, aby nawróceni Chińczycy wyrzekli się praktykowania tych obrzędów. Z ich namowy papież Urban VIII (1623-1644) najpierw potępił (1635) jezuickie praktyki, by - po uzyskaniu dokładniejszych informacji trzy lata później - ponownie je zatwierdzić. Ale już jego następca Innocenty X (1644-1655) ponownie w roku 1645 wypowiedział się na niekorzyść „,chińskich rytuałów” i polecił, by dominikanin Juan Bautista de Morales (1597-1664) wystosował w tej sprawie do jezuitów odpowiednie pismo. Chińscy jezuici nie zgodzili się z poglądami Moralesa i wysłali do Rzymu swojego przedstawiciela, Martino Martiniego (1614-1661), któremu udało się zmienić wcześniejszy pogląd papieża i nakłonić kurię rzymską do wydania dekretu (23 marca 1656), aprobującego jezuickie tolerowanie chińskich rytuałów, przyjętego przez papieża Aleksandra VII (1655-1667).

Kilka lat później do sporu włączył się francuski biskup Charles Maigrot (1652-1730), wikary apostolski w Fukienie i przedstawiciel Société des missions étrangères de Paris w Chinach. Z polecenia papieża Innocentego XII (1691-1700) zbadał on ponownie sprawę „,chińskich rytuałów” i w roku 1693 wystąpił zdecydowanie przeciwko nim, przez co cały spór jeszcze bardziej przybrał na ostrości. W roku 1698 upowszechnił pogląd, według którego stanowisko papieża z roku 1656 było oparte na fałszywych doniesieniach i ,nie da się pogodzić z sumieniem”. Wysłał on do Rzymu dwóch swoich posłańców, aby nakłonili papieża Innocentego XII do ponownego zbadania całej sprawy. Trafiła ona do specjalnej komisji czterech 
kardynałów, która przychyliła się do stanowiska Maigrota, a wsparła to stanowisko także paryska Sorbona (18 października 1700).

Nie próżnowali też jezuici w Pekinie. W roku 1700 wymogli na cesarzu Kangxi (1661-1722) proklamację o cywilnym i świeckim (a nie religijnym) charakterze kultu przodków i Konfucjusza. Wyrządzili tym sobie, zresztą, w Rzymie więcej szkody niż pożytku, byli bowiem przez przeciwników pomówieni o to, że dla rozsądzenia sprawy religijnej odwołali się do osądu „pogańskiego” władcy.

Do tych dwóch sporów, które nosiły zasadniczy charakter, doszły jeszcze pomniejsze kwestie sporne, z których jedna dotyczyła nazywania w języku chińskim chrześcijańskiego Boga. Chińczycy używali od najdawniejszych czasów na określenie „Boga” - w sensie najwyższego bytu, zwierzchniego pana i władcy wszystkiego - dwóch terminów: Tian („Niebo”, „Niebiosa”) oraz Shangdi („Najwyższy cesarz”, „Zwierzchni władca”). Ponieważ późniejsi filozofowie, szczególnie Zhu Xi (1130-1200), według Ricciego nadali pierwszemu z tych określeń znaczenie materialnego, konkretnego, fizycznego nieba, rekomendował on chińskim neofitom, aby dla nazwania chrześcijańskiego Boga (Theos, Deus) używali obok nazwy Shangdi (Supremus Imperator) także określenia Tianzhu - dosłownie „Pan Niebios" (Coeli Dominus).

To, że jezuici w Chinach i w Rzymie zaliczali się do głównych zwolenników polubownego rozwiązywania uprzednio zarysowanych kwestii spornych, miało swoje oczywiste powody. Towarzystwo Jezusowe posiadało w Chinach od samego początku silną pozycję ekonomiczną i mocne wpływy polityczne. Jego członkom, którzy imponowali zarówno mingowskim, jak i mandżurskim władcom swoją wiedzą i umiejętnościami praktycznymi (co w końcu było warunkiem zakwalifikowania się na wyjazd do Chin w ogóle!), powierzano już tradycyjnie ważne i odpowiedzialne zadania na cesarskim dworze. Cesarze i inni wysocy dostojnicy dworscy oddawali im na wychowanie swoich synów, jezuici prowadzili w Pekinie obserwatorium astronomiczne, kierowali dworską orkiestrą, byli thumaczami podczas audiencji udzielanych europejskim poselstwom itd. Być może, więc, to głównie chęć utrzymania prominentnych stanowisk i rozmaitych przywilejów dyktowała im ów powściągliwy stosunek do rozstrzygnięć w prowadzonym z Rzymem sporze o dogmaty.

Zwolennicy radykalnych, a w gruncie rzeczy negatywnych rozstrzygnięć, przeciwstawiający się wszelkim wysiłkom przystosowawczym, byli z kolei motywowani zrozumiałą niechęcią wobec jezuitów, którym zazdrościli wysokich urzędów, tytułów, wielkich majątków i wpływów na dworze. Odnosząc się z pogardą do spuścizny kulturowej wielowiekowych Chin, wspierali wyraźnie papieskie zakazy tolerowania „chińskich rytuałów”, chociaż mądrzejsi z nich zapewne już wówczas przypuszczali, że sztywną postawą szykują własną zgubę.

Kuria rzymska ogłosiła ponownie sprzeciw wobec „chińskich rytuałów” (a tym samym wobec jezuickiego do nich stosunku) w roku 1704. Sprzeciw ten potwierdzi- 
Akomodacja - poprzedniczka aggiornamento?

ła znów w roku 1710, po tym jak osobiści wysłannicy cesarza Kangxi z lat 1706 i 1708 nie zdołali nakłonić ówczesnego papieża Klemensa XI (1700-1721) do zmiany dotychczasowego negatywnego stanowiska.

Jeszcze jednak przed wyruszeniem dwóch cesarskich misji do Rzymu miało miejsce takie oto zdarzenie. W dniu 4 grudnia 1705 r. dotarł do Pekinu legat papieski, biskup Maillard de Tournon (1668-1710), pozornie w celu wyrażenia cesarzowi podziękowania papieża za dotychczasową opiekę nad misjami katolickimi w Chinach, w rzeczywistości zaś z zadaniem upowszechnienia papieskiego zakazu tolerowania wśród nawróconych na chrześcijaństwo „,chińskich rytuałów”. Początkowo legat spotkał się na dworze z okazałym przyjęciem, a cesarz aż trzykrotnie udzielił mu audiencji. Z rozmów wszak rychło wyszło na jaw, jakie są prawdziwe zamiary legata, co wyzwoliło wyraźną niechęć cesarza. Podczas posłuchania 30 czerwca 1706, powracając do kwestii rytuałów, cesarz m.in. oznajmił:

„Proszę przekazać swemu Wielebnemu Kapłanowi, że Chińczycy od dwóch tysięcy lat kierują się nauką Konfucjusza, a także, że od czasów Ricciego, zwłaszcza zaś od czterdziestu lat mojego panowania, zachodnim misjonarzom nie spadł włos z głowy. Jeśli jednak teraz poważą się atakować konfucjanizm, nie będą mogli nadal pozostawać u nas".

Wkrótce potem ukazało się cesarskie obwieszczenie, które zobowiązywało misjonarzy - pod groźbą wygnania - do ubiegania się o cesarskie pozwolenie na swoją misyjną działalność (swego rodzaju placet, po chińsku piao). To piao miało być udzielone tylko tym, którzy zobowiążą się do poszanowania „chińskich rytuałów”. Co więcej, w celu uzyskania obiektywnej informacji na temat rzeczywistego celu misji Tournona cesarz wysłał w roku 1706 do Rzymu dwóch swoich wysłanników; byli nimi pekińscy jezuici, Portugalczyk A. de Berros (1644-1708) i Francuz A. de Beauvollier (1657-1708). Do czasu ich powrotu z Rzymu, Maillard de Tournon miał wstrzymać się z ogłoszeniem zakazu ,chińskich rytuałów”. Legat jednak wezwania cesarza nie posłuchał i 15 stycznia 1707 r. ogłosił w Pekinie papieski dekret. Cesarz zareagował niezwłocznie wydaleniem de Tournona do Makau. Portugalczycy, którzy w obawie o własne pozycje zajęli wobec misji Tournona stanowisko negatywne, wtrącili go do więzienia, gdzie 8 czerwca 1710 r. zmarł.

Ogłoszenie papieskiego zakazu podzieliło chińskich misjonarzy na dwa obozy. Jedni, z oponentem jezuitów Maigrotem (w ówczesnej korespondencji jezuickiej ośmieszanym po łacinie jako „M. Aegrotus”, czyli „Pan Chory”) na czele wśród nich większość dominikanów i część franciszkanów - odrzucili wezwanie do ubiegania się o cesarskie piao i zostali wydaleni z Chin. Pozostali, z biskupem Pekinu włoskim franciszkaninem Bernardino Della Chiesa (1644-1721) na czele, wśród nich oczywiście wszyscy jezuici, odcięli się formalnie od papieskiego legata i wystąpili o wydanie im cesarskiego piao. 
Ponieważ cesarz nie doczekał się powrotu swych dwóch wysłanników do papieża (zatonęli na morzu 20 stycznia 1708 u wybrzeży Portugalii), wyprawił do Rzymu w roku 1708 dwóch dalszych z poleceniem, aby spowodowali odwołanie zapowiedzianego w roku 1704 papieskiego dekretu. Byli to znów jezuici - Francuz A. Provana (1662-1720) i Hiszpan J. R. de Arxo (1659 (60)-1711). Ci wszakże niczego w Rzymie w sprawach „chińskich rytuałów” nie wskórali, dlatego też już do Chin nie wrócili. Tymczasem papież 25 września 1710 wyraził uznanie dla postawy Tournona i ponownie potwierdził swój negatywny stosunek do „chińskich rytuałów”.

$\mathrm{Na}$ tym, niejako, cały spór zakończył się. W rzeczywistości wygasł tylko pozornie, ponieważ w tym czasie przygotowywano już w Rzymie tekst nowej papieskiej konstytucji, która miała zawierać definitywny zakaz „chińskich rytuałów”, wiążący wszystkich misjonarzy działających w Chinach. Konstytucją tą była słynna bulla papieża Klemensa XI Ex illa die z 19 marca 1715. Oczywiście ów tekst nie mógł być jeszcze przez jakiś czas znany w Pekinie. Zarówno cesarz, jak i pekińscy jezuici nadal nie wiedzieli, jakie jest najnowsze stanowisko kurii rzymskiej. Stąd cesarz, wiedziony chęcią wyjaśnienia, dlaczego również jego drugie poselstwo nie powróciło ze swej misji, zdecydował się wysłać do Europy 31 października 1716 r. list otwarty ${ }^{2}$ - według świadectwa działającego w Chinach czeskiego misjonarza Karola Slavička SJ (1678-1735) w nakładzie trzystu egzemplarzy - z zapytaniem, jaki jest wynik jego uprzednich interwencji i sondaży z lat 1706 i 1708 w sprawie chińskich rytuałów. Dla nadania korespondencji powagi i rozwiania $\mathrm{z}$ góry ewentualnych wątpliwości w sprawie autentyczności dokumentu, cesarz zarządził, aby pod łacińską wersją listu otwartego złożyli swoje podpisy dobrze znani w Rzymie przedstawiciele misji katolickiej w Pekinie. Egzemplarze listu miały przewieźć na swych pokładach statki z Europy, które wówczas cumowały w Makau. Pewna ilość listów, zdaje się, wędrowała do Europy także drogą lądową przez Syberię i moskiewską Ruś.

We wspomnianej bulli papieskiej Ex illa die, mającej dla „chińskich rytuałów” kluczowe znaczenie, stwierdza się, co następuje:

W sprawie kultu przodków - „Chrześcijanom nie zezwala się na składanie ofiary bogom w świątyniach albo budowlach poświęconych przodkom. Nie zezwala im się także na wykonywanie ceremonii, posługi lub na samo uczestnictwo w oddawaniu ofiary bogom lub w innych rytuałach i obrzędach tego rodzaju przed tabliczkami przodków, w domach prywatnych lub u grobów zmarłych, czy to zbiorowo z poganami, czy to indywidualnie"s.

\footnotetext{
${ }^{2} \mathrm{Na}$ temat tego cesarskiego listu, zwanego „czerwonym manifestem” (po chińsku hong piao) z powodu cynobrowej barwy druku trójjęzycznego tekstu mandżursko-chińsko-łacińskiego, piszę obszerniej w opublikowanej pod moją redakcją korespondencji Slavička Listy z Činy do vlasti a jiné korespondence s evropskymi hvězdaŕi, 1716-1735, Praha 1995 [Listy z Chin do ojczyzny i inna korespondencja z europejskimi astronomami]

${ }^{3}$ Clementis XI Bullarium, Rzym 1729, s. 429.
} 
Akomodacja - poprzedniczka aggiornamento?

W sprawie hołdu dla Konfucjusza jako świętego - „Wierzącym nie zezwala się, aby ku czci Konfucjusza i zmarłych przodków organizowali uroczyste obrzędy i składali ofiary, albo usługiwali bądź uczestniczyli w nich, ponieważ praktyki te są nacechowane zabobonem. Podobnie nie zezwala się, aby w konfucjańskich świątyniach, które nazywają się po chińsku miao, wierzący wykonywali i organizowali obrzędy, rytuały i składali ofiary ku jego czci"4.

W sprawie, jakiego chińskiego terminu należy używać na określenie chrześcijańskiego Boga, papież opowiedział się za terminem Tianzhu, „Pan Niebios”, pozostałe odrzucił5.

Każdy misjonarz, zanim rozpoczął swą posługę w Chinach, miał odtąd zobowiązać się, że będzie przestrzegał wyżej wymienionych zasad. Był zmuszony stwierdzić to poprzez ustną przysięgę, którą potem potwierdzał swoim podpisem i odsyłał do Rzymu.

Jak dowiadujemy się z listu misjonarza Slavička, datowanego 19 marca $1717 \mathrm{r}$. w Pekinie, bulla papieska dotarła do Kantonu na pokładzie angielskiego statku dopiero po upływie półtora roku od jej wydania, tj. w sierpniu $1716 \mathrm{r}$. i przez pewien czas była trzymana $\mathrm{w}$ tajemnicy przed cesarzem. W Pekinie została ona podana do publicznej wiadomości z polecenia biskupa Della Chiesy w listopadzie 1716 przez jego gorliwego generalnego wikarego Horacjusza z Castorany, za co został wtrącony przez rozgniewanego cesarza do więzienia.

Wydarzenia te wprawiły misjonarzy w Chinach w posępny nastrój i wyzwoliły wśród nich obawy o wydalenie z tego kraju. Cesarz, który powrócił właśnie z Mandżurii do stolicy, nakazał natychmiast zebrać wszystkie egzemplarze papieskiego dekretu i wydał polecenie, aby zostały odesłane do Rzymu. Natomiast oficjalną reakcją cesarskiego dworu było rozporządzenie Kangxi z 16 kwietnia 1717 r., w którym zabronił on dalszego szerzenia wiary chrześcijańskiej w jego cesarstwie, zaś misjonarzom $-\mathrm{z}$ wyjątkiem uczonych w naukach ścisłych i tych, którzy poprosili o zgodę na swoją działalność - zagroził wydaleniem z kraju.

W celu bodaj częściowego złagodzenia negatywnych skutków, jakie miały papieskie zakazy na nowo nawróconych i działających tam misjonarzy, wysłał papież w roku 1720 do Chin nowego legata, którym był aleksandryjski patriarcha Mezzabarba (1685-1741). Ten jednak, nawet ze złagodzoną wersją papieskiej konstytucji (zezwalano np. na klękanie przed tabliczkami przodków i tabliczką Konfucjusza), niczego u cesarza nie wskórał. Nowy cesarz Yongzheng (1723-1735), który zajął miejsce na tronie po swoim ojcu, przyjął wobec chrześcijaństwa postawę negatywną i w żadnej mierze nie sprzyjał jego szerzeniu. Tym samym spór wokół „chińskich rytuałów" zmierzał do swego nieuchronnego końca. Mając na uwadze to, że misja Mezzabarby, podobnie jak uprzednia de Tournona, wiodła do rozłamu wśród

\footnotetext{
${ }^{4}$ Ibidem, s. $428-429$.

${ }^{5}$ Ibidem, s. 428.
} 
chińskich misjonarzy (niektórzy z nich nadal traktowali odstępstwa od obowiązującej bulli Ex illa die za zasadne), sprawa „chińskich rytuałów” była ponownie rozważana przez nowych papieży Klemensa XII (1730-1740) i jego następcę Benedykta XIV (1740-1758). Ustępstwa, z którymi biskup Mezzabarba pojechał do Chin, zostały odwołane, a papieska konstytucja z roku 1715 została potwierdzona w całej rozciągłości. Stało się tak za sprawą bulli Benedykta XIV Ex quo singulari z 11 lipca 1742, w której sprawa ,chińskich rytuałów” została rozstrzygnięta na ich niekorzyść raz na zawsze. (Dwa lata później w bulli tego samego papieża Omnium sollicitudo podobny los spotkał także „malabarskie rytuały” w Indiach). Tak więc Benedykt XIV zadał na długie lata śmiertelny cios wszelkiej działalności misyjnej na Dalekim Wschodzie, a tym samym położył kres odważnemu eksperymentowi akomodacyjnemu Nobilego, Ricciego i ich wybitnych następców.

Stanowisko Benedykta XIV obowiązywało aż do czasów papieży Piusa XI (1922-1939) i Piusa XII (1939-1958), którzy uznali kult Konfucjusza i przodków, „zgodnie z doktryną urzędową i odczuciem powszechnym, za zwyczaje o charakterze świeckim" (Acta Apostolicae Sedis, 1939), przez co stara praktyka akomodacyjna Ricciego została de facto uznana. Akomodacja, w wyobrażeniach i pojmowaniu jej przez jakże dalekowzrocznych inicjatorów i realizatorów, nie przedstawiała właściwie niczego innego, niż pierwszą, swoistą próbę nowoczesnego aggiornamento. Dla misjonarzy w Chinach nie była niczym innym, niż celem, który uświęca środki. Kiedy zaniechano środków (akomodacja), musiał za to zapłacić także cel (głoszenie wiary chrześcijańskiej). Trudno w tym kontekście nie przypomnieć ironicznego spostrzeżenia Woltera, który stwierdził, że spór o chińskie rytuały ,jak mało co innego przyczynił się do zdławienia chrześcijaństwa w Chinach" (Voltaire, Le siècle de Louis XIV, 1751).

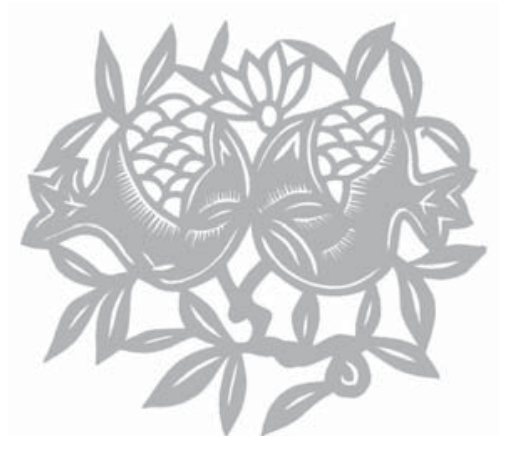

